Volume 10. Nomor 2. December 2015
Pandecta
http://journal.unnes.ac.id/nju/index.php/pandecta

\title{
Kepercayaan Masyarakat terhadap \\ Kinerja Hakim Mahkamah Konstitusi dalam Rangka Penegakan Konstitusi di Indonesia
}

\author{
Arif Sharon Simanjuntak $\bowtie$ \\ Peneliti Pusat Kajian Hukum, Otonomi Daerah dan Demokrasi \\ Universitas Negeri Semarang, Semarang, Indonesia \\ Permalink/DOI http://dx.doi.org/10.15294/pandecta.v10i2.
}

\begin{abstract}
Article History:
Abstrak

Received : August 2015;

Tujuan penelitian ini untuk menganalisis kepercayaan masyarakat terhadap kinerja hakim Accepted: September 2015; Published: September 2015 konstitusi berdasarkan putusan yang saling bertentangan tersebut. Digunakan pendekatan yuridis sosiologis. Metode penelitian yang digunakan adalah metode deskriftif-kualitatif.

Keywords:

trust; constitutional judges performance; constitutional maintenance

Teknik pengumpulan data dilakukan dengan wawancara dan observasi serta studi pustaka. Untuk memeriksa objektifitas dan keabsahan data dilakukan dengan teknik triangulasi data. Hasil penelitian menemukan kepercayaan masyarakat masih tinggi terhadap kinerja hakim konstitusi. Namun, putusan bertentangan yang dikeluarkan oleh Mahkamah Konstitusi menimbulkan kekacauan konstitusional. Akan tetapi tidak ada aturan yang melarang Mahkamah Konstitusi untuk membuat putusan yang bertentangan. Dalam meningkatkan kepercayaan masyarakat Mahkamah Konstitusi harus menjaga transparansinya, meningkatkan kualitas putusan dan integritas hakim. Persepsi atau tingkat kepercayaan masyarakat dapat menjadi faktor pendorong untuk menghilangkan eksistensi sebagai hakim konstitusi bila masyarakat menemukan hakim konstitusi melanggar kode etik dan melakukan tindakan melawan hukum.
\end{abstract}

\begin{abstract}
This research addressess to analyze social trust towards constitutional court judge performance based on contrary constitutional court verdict. This research applies descriptive- qualitative research methodology with socio-legal approach. Observation, interview and documentation methods use to collect data or information. This research found that constitutional court still procure the social trust. However, contrary verdict which issued by constitutional court made a disorder constitution. But there is no regulation to ban the constitutional court issued contrary verdict. To increase the social trust, constitutional court should be transparent, increase the verdict quality and keep the judge integrity well. Perception or social trust can be a stimulation to nullified judges existence if they found that constitutional court judges break the law and disobeyed constitutional judges code of conduct.
\end{abstract}




\section{Pendahuluan}

Mahkamah Konstitusi (MK) memegang peranan yang sangat penting dalam menjaga tegaknya konstitusi di Negara ini. Peranan yang penting tersebut ditunjukkan dengan kewenangan dan kewajiban yang dimiliki oleh Mahkamah Konstitusi dari UUD 1945. Dengan hadirnya MK semakin menguatkan sistem ketatanegaraan kita, dan proses check and balances dalam pemerintahan dapat berjalan semakin efektif. Masyarakat juga memiliki kesempatan yang besar guna memperjuangkan hak-haknya melalui proses judicial review terhadap undang-undang yang dianggap merugikan hak-hak konstitusional mereka. Dalam menjalankan hak dan kewajibannya, Mahkamah Konstitusi memiliki 9 (Sembilan) hakim. Hakim konstitusi harus memiliki sifat khusus seperti diterangkan dalam Pasal 24C ayat (5) UUD 1945 yang berbunyi "Hakim Konstitusi harus memiliki integritas dan kepribadian yang tidak tercela, adil, negarawan yang menguasai konstitusi dan ketatanegaraan, serta tidak merangkap sebagai pejabat Negara". Sifat tersebut diperlukan sebab tanggung jawab menjadi hakim konstitusi begitu besar demi menjamin tegaknya konstitusi.

Cara pemilihan hakim konstitusi di Indonesia dilakukan melalui tiga (3) lembaga tinggi Negara yaitu Mahkamah Agung, DPR dan Presiden yang masing-masing mengajukan 3 orang untuk menjadi hakim konstitusi. Namun belum ada aturan khusus yang mendasari proses seleksi ataupun rekruitmen yang menjadi standar pelaksanaan bagi ketiga lembaga tersebut, hal ini diserahkan kepada otoritas masing-masing lembaga. Dalam Pasal 20 ayat (1) disebutkan "Ketentuan mengenai tata cara seleksi, pemilihan, dan pengajuan hakim konstitusi diatur oleh masing-masing lembaga yang berwenang sebagaimana dimaksud dalam Pasal 18 ayat (1)". Walaupun menjadi kewenangan masing-masing lembaga, dalam proses rekruitmen hakim konstitusi harus lah mematuhi Pasal 19 UU No 24 Tahun 2003 tentang Mahkamah Konstitusi sebagaimana telah diubah dengan UU No 8 Tahun 2011 tentang Perubahan atas UU No 24 Tahun 2003 tentang Mahkamah Konstitu- si, selanjutnya kita sebut UU MK menyatakan "Pencalonan hakim konstitusi dilaksanakan secara transparan dan partisipatif." Permasalahan yang muncul adalah kesempatan publik untuk berpartisipasi masih minim dan masih dianggap proses rekruitmen atau tata cara seleksi masih relatif tertutup.

Munculnya putusan yang berbeda dalam menangani pokok perkara yang sama antara Putusan MK No 072-073/PUU-II/2004 dengan Putusan MK No 97/PUU-XI/2013 menimbulkan sikap kritis di masyarakat terhadap kinerja hakim konstitusi. Kedua putusan tersebut sama-sama menguji tentang rezim Pilkada. Pada Putusan MK No 072-073/ PUU-II/2004 yang pada intinya memutuskan bahwa,

Bahwa ternyata dalam menjabarkan maksud "dipilih secara demokratis" dalam Pasal 18 ayat (4) UUD 1945 pembuat undang-undang telah memilih cara Pilkada secara langsung, maka menurut Mahkamah sebagai konsekuensi logisnya, asas-asas penyelenggaraan pemilihan umum harus tercermin dalam penyelenggaraan Pilkada yaitu langsung, umum, bebas, rahasia, jujur, dan adil (luber-jurdil) yang diselenggarakan oleh lembaga yang independen. Terhadap pendapat apakah Pilkada langsung termasuk kategori pemilu yang secara formal terkait dengan ketentuan Pasal 22E UUD 1945 dan segala peraturan penjabaran dari pasal a quo, Mahkamah berpendapat bahwa Pilkada langsung tidak termasuk dalam kategori pemilihan umum sebagaimana dimaksudkan Pasal 22E UUD 1945. Namun demikian Pilkada langsung adalah pemilihan umum secara materiil untuk mengimplementasikan Pasal 18 UUD 1945. Oleh karena itu dalam penyelenggaraannya dapat berbeda dengan Pemilu sebagaimana dimaksud dalam Pasal 22E UUD 1945, misalnya dalam hal regulator, penyelenggara, dan badan yang menyelesaikan perselisihan hasil Pilkada, meskipun harus tetap didasarkan atas asas-asas pemilihan umum yang berlaku;

Pada intinya putusan tersebut menjadikan sengketa hasil Pilkada berada dibawah penangangan Mahkamah Konstitusi. Namun, munculnya Putusan MK No 97/PUU-XI/2013 
yang pada intinya memutuskan bahwa,

...menurut Mahkamah, dalam memahami kewenangan Mahkamah Konstitusi yang ditentukan dalam Pasal 24C ayat (1) UUD 1945, harus kembali melihat makna teks, original intent, makna gramatika yang komprehensif terhadap UUD 1945. Oleh karena itu, sebagaimana telah diuraikan tersebut diatas, pemilihan umum menurut Pasal 22E UUD 1945 harus dimaknai secara limitative, yaitu pemilihan umum yang diselenggarakan untuk memilih anggota DPR, DPD, Presiden dan Wakil Presiden serta DPRD dan dilaksanakan setap lima tahun sekali...Dengan demikian, jika memasukkan pemilihan kepala daerah menjadi bagian dari pemilihan umum sehingga menjadi kewenangan Mahkamah Konstitusi untuk menyelesaikan perselisihan hasilnya, bukan saja tidak sesuai dengan makna original intent dari pemilihan umum sebagaimana telah diuraikan di atas, tetapi juga akan menjadi Pemilu tidak saja setiap lima tahun sekali, tetapi berkali-kali, karena pemilihan kepala daerah sangat banyak dilakukan dalam setiap lima tahun dengan waktu yang berbeda-beda.

Pada intinya putusan tersebut menolak menyatakan bahwa wewenang untuk mengadili sengketa hasil Pilkada adalah bagian dari wewenang Mahkamah Konstitusi. Putusan yang saling bertentangan tersebut tentu menimbulkan kebingungan di masyarakat, sebab sifat putusan MK adalah final and binding.

Selain itu, kita juga mengetahui kasus yang menimpa Akil Mochtar sewaktu menjabat sebagai hakim ketua Mahkamah Konstitusi yang mana tertangkap tangan oleh KPK (Komisi Pemberantasan Korupsi) pada tahun 2013 dengan tuduhan menerima hadian dan suap atas perkara pemilihan kepala daerah di Kabupaten Gunung Mas, Kalimantan Tengah dan Kabupaten Lebak, Banten. Kejadian ini memberikan dampak yang luar biasa terhadap degradasi kepercayaan masyarakat terhadap kinerja hakim konstitusi yang dianggap meruntuhkan marwah lembaga yang dianggap sebagai gerbang terakhir penegakan konstitusi. Kasus penangkapan ini dianggap menim- bulkan keadaan darurat oleh pemerintah saat itu hingga akhirnya mengeluarkan Perpu No 1 Tahun 2013 untuk menyelamatkan Mahkamah Konstitusi dari krisis kepercayaan.

Sebagai Negara hukum, Indonesia harus benar-benar menjunjung hukum yang berlaku. Artinya setiap tindakan yang dilakukan oleh pemerintah harus mempunyai payung hukum yang benar, namun ada kalanya hukum dalam bentuk undang-undang seolah tidak sesuai dengan amanat konstitusi kita, sehingga peranan Mahkamah Konstitusi menjadi penting untuk meluruskannya. Sumber dari segala hukum di Indonesia adalah Pancasila, sehingga setiap hukum yang tidak sesuai atau bertentangan dengan Pancasila haruslah dikoreksi oleh Mahkamah Konstitusi melalui proses judicial review. Proses koreksi tersebut menjadi sebuah bentuk pengawasan terhadap kinerja pemerintahan yang ada atau yang dapat kita sebut check and balances. Proses check and balances dimana Mahkamah Konstitusi berperan sebagai pihak yang netral. Sebab kita mengetahui kewenangan yang dimiliki oleh pemerintahan yang ada dapat saja disalahgunakan sehingga menciderai hak-hak konstitusional warga negaranya. Hakim dalam mengeluarkan putusan juga haruslah benar-benar memahami konstitusi, sehingga putusan yang dikeluarkan tidak menimbulkan kebingungan di masyarakat. Hakim harus pula dapat merespon keinginan masyarakat untuk mendapatkan perlindungan atas hak-hak konstitusional mereka seperti dalam teori hukum responsif John Henry Marryman. Seperti yang dijelaskan oleh Martitah dalam bukunya yang berjudul Mahkamah Konstitusi Dari Negative Legislature ke Positive Legislature (2013:38-39),

Pembentukan hukum oleh hakim dalam konsep hukum responsif dari John Henry Marryman menyatakan bahwa seorang hakim hakim sering berpikir bahwa perundang-undangan sebagai salah satu bentuk pelayanan dari fungsi tambahan yang sering kurang akurat. Oleh karenanya hakim dalam melakukan interpretasi harus mengisi celah dan menyelesaikan masalah dalam skema perundangan. Hakim harus mengubah hukum terhadap kondisi/kenyataan yang beru- 
bah-ubah. Perundangan bukan sesuatu yang pasti dalam penggunaannya khususnya pada hakim yang bijaksana.

Efektivitas keberlakuan putusan yang dikeluarkan oleh Mahkamah Konstitusi pastinya harus didukung oleh kepercayaan dari masyarakat. Dalam hal ini, masyarakat harus mempercayai kinerja hakim konstitusi sehingga mereka tidak meragukan putusan yang dikeluarkan oleh lembaga tersebut. Kepercayaan masyarakat terhadap kinerja hakim akan mendukung kinerja hakim dalam menerbitkan putusan yang melindungi hak konstitusional warga Negara. Kepercayaan atau (trust) menjadi salah satu modal bagi Mahkamah Konstitusi untuk semakin meningkatkan pelayanannya. Sebab bila putusan yang dikeluarkan oleh hakim konstitusi menimbulkan kecurigaan dan social distrust tentu akan menghambat pembangunan hukum dan kemajuan Negara. Putusan hakim konstitusi harus benar-benar menjadikan suasan di masyarakat menjadi saling mempercayai, dengan demikian sebagai timbal baliknya kepercayaan terhadap kinerja hakim juga akan semakin meningkat. Martitah (2013:114-115) menjelaskan bahwa trust atau kepercayaan merupakan bagian dari modal sosial, "Trust merupakan sikap saling mempercayai di masyarakat yang memungkinkan masyarakat tersebut saling bersatu dengan yang lain memberikan pada peningkatan modal sosial. Tingkat kepercayaan antara satu anggota masyarakat dengan anggota yang lainnya, terhadap kelompoknya akan mendukung partisipasi masyarakat dalam rangka membangun kemajuan bersama, sebaliknya kencuran tingkat kepercayaan tersebut akan menjadi problem sosial yang bisa menghambat pengembangan tujuan-tujuan bersama."

\section{Metode Penelitian}

Sunggono (2013:78) menjelaskan penelitian empiris atas hukum akan menghasilkan teori-teori tentang eksistensi dan fungsi hukum dalam masyarakat, berikut perubahan-perubahan yang terjadi dalam prosesproses perubahan sosial. Teori-teori inilah yang kemudian lebih terkenal dengan "the social theories of law" dan seluruh kajiannya disistematisasi kedalam kajian "Hukum dan Masyarakat"(law and society). Metode penelitian yang digunakan dalam hal ini adalah kualitatif, sedangkan digunakan analisis data dilakukan secara deskriptif. Fokus penelitian adalah untuk menganalisis tingkat kepercayaan masyarakat terhadap kinerja hakim konstitusi dan penguatan lembaga peradilan Mahkamah Konstitusi dimulai dari sistem rekruitmen hingga faktor-faktor yang mempengaruhi hakim dalam mengeluarkan putusan. Sumber data terdiri dari data primer dan data sekunder yang dikumpulkan dengan melakukan obervasi, wawancara dan pengumpulan dokumentasi ilmiah. Dalam mendapatkan data yang valid digunakan teknik triangulasi data. Dimana dalam hal ini informasi yang didapatkan dari hasil wawancara kemudian dibandingkan dengan hasil observasi yang dilakukan oleh peneliti. Setelah mendapatkan data-data yang dibutuhkan, peneliti kemudian melakukan analisis terhadap data-data tersebut. Dalam proses analisis data, dilakuakn reduksi data dalam hal ini reduksi data dilakukan untuk memilih, memusatkan perhatian hanya pada pokok permasalahan yang dibahas saja sehingga memberikan gambaran yang lebih jelas terhadap hasil pengamatan. Reduksi data dilakukan sebab jumlah informasi dan data yang diperoleh dari hasil observasi dan wawancara begitu banyak sehingga perlu dipilah. Langkah terakhir adalah melakukan penarikan kesimpulan. Penarikan kesimpulan terkait dengan kepercayaan masyarakat terhadap kinerja hakim konstitusi dan bagaimana upaya untuk meningkatkan kepercayaan masyarakat terhadap Mahkamah Konstitusi.

\section{Hasil Penelitian dan Pembahasan}

\section{Tingkat Kepercayaan Masyarakat Terha- dap Kinerja Hakim Mahkamah Konstitusi Dalam Penegakan Konstitusi}

Sebagai Negara hukum, hukum di Indonesia harus paling tidak sudah sesuai dengan konsep the rule of law, kita dapat memperhatikan hasil konferensi International Commision of Jurist yang mengemukakan 
syarat-syarat dasar the rule of law, yaitu:

a. Perlindungan konstitusional, dalam arti bahwa konstitusi selain menjamin hakhak individu harus menentukan juga cara prosedural untuk memperoleh perlindungan atas hak-hak yang dijamin;

b. Badan kehakiman yang bebas dan tidak memihak (independent and impartial tribunals);

c. Pemilu yang bebas

d. Kebebasan menyatakan pendapat, berorganisasi atau berserikat dan beroposisi;

e. Pendidikan

(Hidayat, 2011:7)

Sebelum masa reformasi, dapat dikatakan bahwa kelima syarat-syarat dasar Negara hukum belumlah secara maksimal dapat diwujudkan di Indonesia. Sebab pada masa itu, kekuasaan eksekutif yang begitu besar yang dapat mempengaruhi semua aspek kegiatan penyelenggaraan bernegara baik legislative dan yudikatif. Mahkamah Konstitusi lahir dari keinginan untuk penegakan konstitusi di Negara ini. Hal ini disebabkan karena sebelum lahirnya Mahkamah Konstitusi, keadaan Hukum Tata Negara yang identik dengan konstitusi di Indonesia begitu amburadul. Dimana dalam penegakan hukum, intervensi politik sangat besar yang menyebabkan kerugian-kerugian konstitusional. Menurut Sri Soemantri (2014:4) hal ini diperkuat lagi ketika pada kurun waktu 1959-1998 di Indonesia dengan meminjam istilah Mahfud MD, berlaku konfigurasi politik totaliter. Selama berlakunya konfigurasi politik seperti itu, penguasa Negara seringkali memanipulasi Hukum Tata Negara agar mendukung kepentingan pribadi atau kelompok penguasa tersebut.

Lahirnya Mahkamah Konstitusi, menjadi angin segar bagi penegakan konstitusi dinegara ini. Hal ini dibuktikan dengan banyaknya undang-undang yang dilakukan judicial review dan banyak yang dinyatakan melanggar konstitusi sehingga dibatalkan berlakunya. Adanya peluang yang dimiliki untuk melakukan judicial review tentu saja semakin menguatkan sistem check and balances di Negara kita. Dengan berjalannya sistem check and balances, Mahkamah Konstitusi mengambil peranan sebagai pihak yang mengawasi dan menguji produk hukum yang dikeluarkan oleh pemerintahan saat ini apakah sudah sesuai amanat konstitusi atau tidak.

Kinerja hakim konstitusi secara menyeluruh dari periode 2003-2015 sudah cukup baik. Hal ini dibuktikan dengan banyaknya masyarakat yang melakukan judicial review kepada Mahkamah Konstitusi, walaupun pada masa kepemimpinan Akil Mochtar terjadi guncangan yang sangat besar dimana Akil Mochtar tertangkap tangan menerima suap. Hal ini tentu saja mempengaruhi kepercayaan masyarakat terhadap kinerja Mahkamah Konstitusi khususnya hakim-hakim konstitusi. Pelanggaran tersebut akan membangun persepsi masyarakat yang memberikan pengaruh terhadap eksistensi hakim konstitusi tersebut. Namun, di Indonesia tidak mudah mengukur apakah sebuah putusan tersebut akan menimbulkan kepercayaan publik terhadap Mahkamah Konstitusi, sebab seperti yang kita pahami bahwa Mahkamah Konstitusi memiliki empat kewenangan dalam memutus yang tentu setiap putusan yang dikeluarkan memunculkan pandangan yang tidak sama pada masyarakat.

Dalam proses wawancara penulis dengan Prof. Bagir Manan, ada beberapa alasan yang disampaikan oleh Prof. Bagir Manan dalam memandang bagaimana sulitnya mengukur kepercayaan masyarakat terhadap Mahkamah Konstitusi berdasarkan putusan yang dikeluarkannya, yaitu;

1. Karena putusan Mahkamah Konstitusi yang beraneka ragam. Contohnya sifat perkara menguji UU dengan Pilkada berbeda, dan itu akan mempengaruhi kepercayaan masyarakat, tergantung pada putusan yang mana dilakukan pengujian.

2. Kepentingan yang berbeda. Contohnya tingkat kepercayaan publik harus dapat ditentukan berada dimana, sebab publik yang mendukung pasangan yang kalah dalam mengajukan PHPU ke MK tentu akan berharap putusan 
yang dikeluarkan Mahkamah Konstitusi adalah sesuai dengan apa yang mereka inginkan, namun bertolak belakang dengan apa yang diharapkan oleh pasangan yang menang.

3. Nuansa politik dari putusan Mahkamah Konstitusi. Artinya, Mahkamah Konstitusi sebagai badan peradilan diharapkan jauh dari unsur-unsur politik, namun pada faktanya hal itu sangat susah untuk dilakukan sebab pandangan bahwa undang-undang adalah produk politik sedangkan Mahkamah Konstitusi memiliki kewenangan untuk menguji undangundang terhadap UUD yang dianggap sebagai produk politik. Apalagi Mahkamah Konstitusi juga menangani kasus sengketa Pilkada, yang mana dalam hal ini Pilkada adalah proses politik, tentu hal ini berpengaruh terhadap kepercayaan publik kepada putusan Mahkamah Konstitusi.

4. Kualitas dari hakim. Kita memahami bahwa dalam perkara pengujian undang-undang merupakan perkara yang sangat konstitusional, oleh karena itu pemahaman hakim akan konstitusi harus sangat baik, karena melibatkan konsep-konsep Hukum Tata Negara yang sangat mendalam, walaupun dalam kasus lain melibatkan konsepkonsep hukum yang lain seperti konsep pemidanaan dan keperdataan. Namun karena menyangkut konstitusi, sifat putusan Mahkamah Konstitusi harus mencerminkan prinsip-prinsip konstitusional yang mendalam. Karena menyangkut konsep-konsep, putusan Mahkamah Konstitusi tidak boleh hanya analisis normative saja namun analisis konsep menjadi sangat penting.

Namun demikian, secara keseluruhan kita dapat menyatakan bahwa masyarakat masih menaruh kepercayaan yang cukup tinggi terhadap hakim-hakim konstitusi sampai pada saat ini. Kepercayaan tersebut tetap ada dikarenakan kinerja hakim pasca tertangkapnya Akil Mochtar cukup baik sehingga dapat mengembalikan wibawa Mahkamah Konstitusi menjadi lembaga yang terpercaya. Ukuran kepercayaan dapat dilihat berdasarkan kepercayaan masyarakat untuk tetap mengajukan judicial review dan bagaimana rakyat tetap menjalankan putusan-putusan Mahkamah Konstitusi.

Hal ini dapat kita lihat melalui rekapitulasi table Pengujian Undang-Undang dibawah ini.

Tabel 1 Rekapitulasi Pengujian Undang-Undang di Mahkamah Konstitusi

\begin{tabular}{|c|c|c|c|c|c|c|c|c|c|c|c|}
\hline \multirow[b]{2}{*}{ No } & \multirow[b]{2}{*}{ Tahun } & \multirow{2}{*}{$\begin{array}{c}\text { Dalam } \\
\text { Proses } \\
\text { Yang Lalu }\end{array}$} & \multirow[b]{2}{*}{ Terima } & \multirow[b]{2}{*}{ Jumlah } & \multicolumn{4}{|c|}{ Amar Putusan } & \multirow{2}{*}{$\begin{array}{l}\text { Jumlah } \\
\text { putusan }\end{array}$} & \multirow{2}{*}{$\begin{array}{c}\text { Dalam } \\
\text { proses } \\
\text { tahun ini }\end{array}$} & \multirow{2}{*}{$\begin{array}{c}\text { Jumlah } \\
\text { UU yang } \\
\text { diuji }\end{array}$} \\
\hline & & & & & Kabul & Tolak & $\begin{array}{c}\text { Tidak } \\
\text { diterima }\end{array}$ & $\begin{array}{c}\text { Tarik } \\
\text { kembali }\end{array}$ & & & \\
\hline 1 & 2003 & 0 & 24 & 24 & 0 & 0 & 3 & 1 & 20 & 20 & 16 \\
\hline 2 & 2004 & 20 & 27 & 47 & 11 & 8 & 12 & 4 & 35 & 12 & 14 \\
\hline 3 & 2005 & 12 & 25 & 37 & 10 & 14 & 4 & 0 & 28 & 9 & 12 \\
\hline 4 & 2006 & 9 & 27 & 36 & 8 & 8 & 11 & 2 & 29 & 7 & 9 \\
\hline 5 & 2007 & 7 & 30 & 37 & 4 & 11 & 7 & 5 & 27 & 10 & 12 \\
\hline 6 & 2008 & 10 & 36 & 46 & 10 & 12 & 7 & 5 & 34 & 12 & 18 \\
\hline 7 & 2009 & - & - & - & - & - & - & - & - & - & - \\
\hline 8 & 2010 & 39 & 81 & 120 & 17 & 23 & 16 & 5 & 61 & 59 & 58 \\
\hline 9 & 2011 & 59 & 86 & 145 & 21 & 29 & 35 & 9 & 94 & 51 & 55 \\
\hline 10 & 2012 & 51 & 118 & 169 & 30 & 31 & 30 & 6 & 97 & 72 & 0 \\
\hline 11 & 2013 & 72 & 109 & 181 & 22 & 52 & 23 & 13 & 110 & 71 & 64 \\
\hline 12 & 2014 & 71 & 140 & 211 & 29 & 41 & 43 & 18 & 131 & 80 & 71 \\
\hline 13 & 2015 & 80 & 46 & 126 & 3 & 14 & 24 & 4 & 45 & 81 & 0 \\
\hline 14 & Jumlah & 430 & 749 & 1179 & 163 & 243 & 215 & 72 & 695 & & 329 \\
\hline
\end{tabular}

Sumber: http://www.mahkamahkonstitusi.go.id/index.php?page =web.RekapPHPUD, diakses pada 14/04/2015 pada pukul 11.02 wib 


\section{Analisis Kepercayaan Masyarakat Terha- dap Kinerja Hakim Konstitusi Berbasis Putusan MK No 072-073/PUU-II/2004 Dengan Putusan MK No 97/PUU-XI/2013}

Putusan MK No 072-073/PUU-II/2004 pada intinya menjadikan penyelesaian sengketa hasil Pilkada menjadi wewenangan MK karena dianggap bagian dari Pemilu. Namun pada Putusan MK No 97/PUU-XI/2013 membatalkan putusan MK No 072-073/ PUU-II/2004 dengan alasan bahwa dalam kewenangan Mahkamah Konstitusi tidak disebutkan bahwa Mahkamah Konstitusi juga menangani sengketa hasil Pemilihan Kepala Daerah. Dalam Putusan MK No97/PUU$\mathrm{XI} / 2013$ lebih lanjut mengatakan bahwa dalam memahami kewenangan MK harus melihat makna teks, original intent, makna gramatika yang komprehensif terhadap UUD 1945. Menurut MK, pemilihan umum harus dimaknai secara limitative dengan memasukkan Pilkada menjadi bagian dari Pemilu akan tidak seshai dengan makna original intent. Menurut penulis hal ini disebabkan pembuat UUD kita memahami bahwa Pilkada berbeda dengan Pemilu, walaupun menggunakan juga sebagian asas-asas pemilu. Penafsiran terhadap Pasal 18 ayat (4) UUD 1945, harus lah ditafsirkan secara sistematis, walaupun setiap pasal dalam UUD 1945 saling berkaitan namun bukan berarti kita dapat menggabungkan dua pasal yang berbeda dalam dua bab yang berbeda menjadi satu penafsiran yang sama. Oleh karena itu, menurut penulis harus ada masukan terkait penyelesaian sengketa hasil Pilkada setelah tidak ditangani oleh Mahkamah Konstitusi.

Bila demikian, maka putusan Mahakamah Konstitusi yang bertentangan ini tentu akan menimbulkan kebingungan di masyarakat. Sebab, Mahkamah Konstitusi sendiri sudah menangani banyak perkara sengketa pilkada sebanyak 698 perkara dan menyatakan bahwa itu adalah kewenangan Mahkamah Konstitusi. Hal ini yang membuat penulis menjadikan kedua putusan ini sebagai basis penulis untuk mengkaji bagaimana kepercayaan masyarakat terhadap kinerja hakim. Masyarakat sudah menerima putusan tentang sengketa Pilkada sebanyak 698 kali.
Dalam putusannya, Mahkamah Konstitusi mengakui bahwa penanganan perselisihan hasil Pilkada adalah kewenangannya, namun dengan dikeluarkannya Putusan MK No 97/ PUU-XI/2013 yang pada intinya menyatakan penyelesaian sengketa Pilkada bukan wewenangnya tentu akan menimbulkan kebingungan masyrakat. Kualitas hakim ditentukan oleh putusan yang dikeluarkannya, dan bila putusan dikeluarkan berbeda dengan putusan terdahulu pastilah akan menimbulkan tanda tanya besar di masyarakat tentang kinerja hakim tersebut.

Menurut Prof. Bagir Manan, dalam membuat putusan yang berbeda, Mahkamah harus menemukan terlebih dahulu beberapa hal:

a) Perbedaan nya apakah bersifat substantif,

b) Ada kebaruan pada pokok permasalahan yang akan diputuskan, dan

c) Apakah perbedaan yang ditemukan dapat menyakinkan bahwa putusan terdahulu adalah salah.

Penulis menilai bahwa Mahkamah memiliki dasar yang kuat dan beberapa hal yang dijadikan tolak ukur oleh Prof. Bagir Manan juga dapat dipenuhi oleh putusan MK yang terbaru untuk membuat putusan yang berbeda yang dapat kita temukan setelah membaca kedua putusan tersebut. Sifat putusan Mahkamah Konstitusi adalah final and binding, namun sistem hukum kita menganut sistem Eropa Kontinental, dimana putusan hakim terhadulu tidak wajib untuk diikuti. Hal ini memberikan kemungkinan adanya putusan Mahkamah Konstitusi yang saling bertentangan satu sama lain. Namun, adalah sebaiknya bila putusan tidak saling bertentangan, apalagi putusan tersebut dikeluarkan oleh Mahkamah Konstitusi sendiri, dan putusan bersifat final and binding. Terhadap nasib sengketa Pilkada yang sudah ditangani Mahkamah Konstitusi sebelum keluarnya Putusan MK Nomor 97/PUU-XI/2013 berlaku prinsip "presumption iustitia casua", yang berarti harus dinyatakan benar, valid dan berlaku sah sepanjang tidak dicabut oleh pembentuknya atau dinyatakan tidak mempunyai kekuatan hukum mengikat oleh Mahkamah. 
Namun sebuah dilema bagi MK, bila melihat kepada kondisi sosio-politik di masyarakat terkait siapa yang akan menyelesaikan sengketa hasil pilkada. Walaupun MK sudah memutuskan untuk tidak menangani sengketa hasil Pilkada, namun masyarakat masih menginginkan MK untuk menanganinya. Penulis melihat bahwa MK tersandera oleh putusan inkonstitusional yang telah dibatalkannya melalui putusan MK No 97/ PUU-XI/2014. Menurut penulis telah terjadi kekacauan konstitusional yang tidak mendapat respon cepat dari pemerintahan saat ini. Sebab bila MK tetap menerima penyelesaian sengketa hasil pilkada tentu saja MK sudah mengingkari putusannya sendiri, namun dilain sisi bahwa telah diperoleh kesepakatan MK tetap dipercaya untuk menangangi sengketa hasil pilkada sebab MA menolak untuk kembali untuk menanganinya.

Dukungan agar MK tetap menyelesaikan sengketa hasil Pilkada juga disampaikan oleh Jimly Ashidiqie, sebab menurutnya MK harus tunduk kepada UU dan menaati putusan MK terdahulu yang menyatakan bahwa MK berhak untuk menangani sengketa hasil Pilkada. Dalam pandangannya, Pemilu nasional adalah sama dengan Pilkada karena keduanya sama-sama diselenggarakan oleh KPU (Komisi Pemilihan Umum), yang berarti kewenangan untuk menangani sengketa hasil Pilkada adalah bagian dari kewenangan MK. Dukungan juga diberikan oleh Fadli Ramadhanil, seorang Peneliti Hukum Perkumpulan untuk Pemilu dan Demokrasi (Perludem). Menurutnya lembaga ideal yang mampu menangangi sengketa hasil Pilkada saat ini adalah MK, sebab MK sudah teruji menyelesaikan sengketa hasil Pilkada dari rentang waktu 2008-2012 dengan hasil memuaskan.

Sedangkan Bawaslu walaupun menyatakan siap untuk menangani hasil Pilkada bukan jalan keluar yang bijak sebab Bawaslu di desain tidak untuk menyelesaikan sengketa hasil pilkada. Sehingga MK adalah pilihan yang paling rasional untuk penyelesaian sengketa Pilkada yang jujur dan adil. Pendapat berbeda disampaikan oleh Refly Harun, menurutnya sengketa hasil pilkada sebaiknya diserahkan kepada Bawaslu. Alasannya adalah, Bawaslu memiliki tiga kewenangan yang bila diperkuat merupakan lembaga yang sesuai untuk menyelesaikan sengketa hasil pilkada, yaitu pengawasan, penangangan tindak pidana pemilu, dan penyelesaian sengketa dalam konteks pemilu legislatif. Kewenangan yang dimiliki Bawaslu bila dimaksimalkan akan menjadi solusi dalam menangangi sengketa hasil pilkada pasca putusan MK No 97/PUU$\mathrm{XI} / 2013$, sebab menurutnya permasalah dalam pilkada biasanya adalah tidak jelasnya pengawasan.

Penulis melihat permasalahan yang dihadapi lebih dari masalah kepercayaan masyarakat yang tetap mempercayakan MK menangani hasil pilkada. Permasalahan yang dihadapi saat ini adalah permasalahan tertib konstitusi dan kepatuhan terhadap konstitusi. Namun, kepercayaan yang diberikan masyarakat kepada MK juga sebai bentuk pengejawantahan kedaulatan rakyat lebih tinggi daripada putusan MK, sebab pada pasal 1 ayat (2) UUD 1945 menyebutkan "Kedaulatan berada ditangan rakyat dan dilaksanakan menurut Undang-Undang Dasar". Artinya trust atau kepercayaan dari masyarakat menjadi alasan yang paling logis bagi MK untuk tetap menyelesaikan sengketa hasil pilkada walaupun putusan MK sudah menyatakan tidak menangangi sengketa hasil pilkada. Kedaulatan rakyat menjadi kedaulatan tertinggi yang dapat mengalahkan kekuatan erga omnes dan putusan final and binding dari MK. Namun demikian, bagi penulis penyelesaian sengketa hasil Pilkada harus kembali ditangani oleh Mahkamah Agung, sebab hal itu adalah amanat konstitusi yang harus dijalankan oleh Mahkamah Agung. Mahkamah Agung harus berani mengambil langkah ini sebagai usaha untuk mengembalikan kepercayaan masyarakat terhadap Mahkamah Agung. Untuk itu Mahkamah Agung harus segera melakukan perbaikan-perbaikan yang sangat besar, artinya mereka dalam bersidang harus terbuka dan tidak berlaku curang. Masyarakat harus dapat mengawasi dengan langsung proses sidang sengketa hasil Pilkada. Bila Mahkamah Konstitusi memperoleh kepercayaan yang begitu besar dari masyarakat untuk tetap menangani sengketa hasil Pilkada artinya Mahkamah Agung juga dapat mendapatkan kepercayaan tersebut. 
Untuk mengembalikan kepercayaan tersebut Mahkamah Agung harus mengikuti langkah-langkah yang dilakukan oleh Mahkamah Konstitusi dalam menangangi sengketa hasil Pilkada, atau dilakukan transfer of system atau transfer of knowledge terkait penangangan sengketa hasil pilkada yang transparan dan akuntabel.

Perkembangan terbaru adalah Mahkamah Konstitusi tetap menangani Sengketa Hasil Pemilukada sampai terbentuknya pengadilan khusus yang menangani sengketa hasil Pemilukada. Untuk menyelesaikan sengketa hasil pilkada serentak tahun 2015 Mahkamah Kontitusi mengeluarkan Peraturan Mahkamah Konsitusi Nomor 05 tahun 2015 Tentang Perubahan Atas Peraturan Mahkamah Konstitusi Nomor 1 Tahun 2015 Tentang Pedoman Beracara Dalam Perkara Perselisihan Hasil Pemilihan Gubernur, Bupati, Dan Walikota, Peraturan Mahkamah Konsitusi Nomor 06 tahun 2015 Tentang Perubahan Atas Peraturan Mahkamah Konstitusi Nomor 4 Tahun 2015 Tentang Pedoman Beracara Dalam Perkara Perselisihan Hasil Pemilihan Gubernur, Bupati, Dan Walikota Dengan Satu Pasangan Calon, Peraturan Mahkamah Konsitusi Nomor 07 tahun 2015 Tentang Perubahan Atas Peraturan Mahkamah Konstitusi Nomor 2 Tahun 2015 Tentang Tahapan, Kegiatan, Dan Jadwal Penanganan Perkara Perselisihan Hasil Pemilihan Gubernur, Bupati, Dan Walikota, dalam PMK tersebut menjadi pedoman bagi Mahkamah Konstitusi untuk menyelesaikan sengketa hasil Pilkada serentak pada Desember 2015.

\section{Upaya Meningkatkan Kepercayaan Ma- syarakat Terhadap Kinerja Hakim Mahka- mah Konstitusi Dalam Rangka Penegakan Konstitusi}

Kinerja hakim konstitusi yang baik, dalam bentuk putusannya juga tentu akan semakin mendorong masyarakat memiliki kesadaran konstitusi yang semakin baik. Dengan semakin baiknya kesadaran konstitusi masyarakat, masayrakat akan semakin pro aktif dalam mengawal dan mengawasi kiner- ja pemerintah dan wakil rakyat dalam menjalankan amanat konstitusi, dengan demikian tujuan untuk menjadi Negara yang sejahtera dapat lebih cepat dicapai.

Berdasarkan penelitian yang dilakukan penulis, bahwa dalam upaya untuk meningkatkan kepercayaan masyarakat terhadap kinerja hakim konstitusi dipengaruhi oleh halhal dibawah ini.

a. Transparansi dan perbaikan kualitas pelayanan.

Mahkamah Konstitusi juga dalam pelayanannya kepada masyarakat harus tetap menjaga transparansinya dan selalu memperbaiki kualitas pelayanannya. Perbaikan kualitas pelayanan disertai dengan monitoring dan evaluasi yang dilakukan secara berkala. Hakim-hakim konstitusi juga harus selalu menjaga integritasnya, menjaga perilaku dan selalu mematuhi Kode Etik Hakim Konstitusi. Putusan-putusan yang dikeluarkan haruslah dengan keadilan substantif. Putusan Mahkamah tidak boleh hanya didasarkan pada penafsiran-penafsiran yang dangkal dan pada keadilan-keadilan pragmatis serta didasarkan pada kondisi sosial-politik sesaat dimasyarakat.

Adalah sangat sulit memang untuk membuktikan bahwa seorang hakim dalam mengeluarkan putusan berada dalam intervensi pihak lain. Salah satu cara agar dapat mengidentifikasi intervensi ini biasanya dilihat dari kualitas putusan yang dikeluarkan. Namun, kita juga harus sadar bahwa mafiamafia hukum dan peradilan bukanlah orangorang yang tidak paham hukum, mereka juga adalah para pakar hukum dengan kemampuan penguasaan hukum yang sangat baik. Sehingga dalam menganalisis putusan juga dibutuhkan orang-orang dengan pemahaman hukum yang sangat baik. Terlalu naif bila kita mengatakan bahwa hakim tidak dapat dipengaruhi oleh pihak lain dalam membuat sebuah putusan. Hakim Mahkamah Konstitusi sekalipun dapat dipengaruhi independensinya oleh pihak lain, seperti pernyataan Dr. Ni'matul Huda selalu ada mafia hukum dan peradilan, namun seperti hantu, kita mengetahui ada namun sangat sulit untuk melihat wujudnya. 


\section{b. Self restricted}

Dalam menjaga independensi dan integritas hakim konstitusi, harus dapat membatasi diri baik dalam menerima putusan dan dalam pergaulannya. Membatasi putusan yang dalam hal tidak menerima hal-hal yang berkaitan dengan permasalahan-permasalahan politik. Sebab pada dasarnya hakim konstitusi tidak boleh tersandera masalah politik serta tidak boleh berpolitik. Hakim konstitusi haruslah netral dan tidak memiliki hubungan yang dekat dengan salah satu partai politik dinegara ini. Menjaga marwah dan martabat jabatan hakim konstitusi yang agung sangatlah penting. Dengan demikian hakim konstitusi akan dapat menjalankan tugas dengan baik, serta tidak akan mendapatkan beban serta intervensi dari pihak lain karena hubungan atau kedekatan dengan pihak lain dikarenakan hakim konstitusi tidak membatasi diri dalam pergaulannya.

Dalam penelitian yang dilakukan penulis, menurut Prof. Bagir Manan, masih banyak hakim di Indonesia yang tidak membatasi pergaulannya. Contoh yang disampaikan oleh Prof. Bagir Manan adalah, hakim masih sering pada jam istirahat atau makan siang ditempat yang dimana pihak-pihak yang bersengketa dapat bertemu dengan hakim tersebut. Sehingga dengan demikian dimungkinkan terjadinya kongkalikong antara hakim dengan pihak-pihak yang bersengketa sehingga mempengaruhi independensi hakim dalam mengeluarkan putusan. Menurut pengalaman penulis yang pernah melakukan Praktek Kerja Lapangan (PKL) di Mahkamah Konstitusi, temuan penulis adalah para hakim selalu makan siang didalam gedung Mahkamah Konstitusi dalam ruangan khusus. Bila independensi hakim konstitusi dilihat dari hal ini tentu saja dapat dikatakan tidak akan ada intervensi dari pihak lain sebab tidak akan ada kesempatan bagi pihak yang berperkara untuk bertemu hakim sewaktu jam istirahat atau jam makan siang.

\section{c. Sistem rekruitmen hakim konstitusi.}

Rekruitmen hakim konstitusi memiliki hubungan langsung dengan kinerja hakim konstitusi. Dalam melihat kinerja hakim konstitusi, kita tidak dapat melepaskannya dari proses rekruitmen dan sistem rekruitmen yang digunakan. Penulis berpendapat bahwa sistem rekruitmen yang baik tentu akan menghasilkan hakim yang baik pula. Namun bila sistem rekruitmennya tidak baik dan dipengaruhi oleh kepentingan politik penyelenggara maka hakim yang terpilih pasti hakim yang dianggap dapat bekerjasama dengan mereka. Dalam penelitian yang penulis lakukan, penulis menemukan bahwa sistem rekruitmen hakim konstitusi belum begitu transparan. Padahal dalam Pasal 19 Undang-Undang Mahkamah Konstitusi disebutkan dalam hal pencalonan hakim mahkamah konstitusi harus bersifat transparan dan partisipatif.

Berdasarkan hasil observasi dan pengamatan penulis, Mahkamah Agung merupakan lembaga yang masih tertutup dalam hal rekruitmen hakim konstitusi diantara lembaga lain yaitu DPR dan Pemerintah. Namun, dalam menanggapi ketertutupan tersebut, Prof. Bagir Manan, memberikan jawaban bahwa undang-undang sudah memberikan kewenangan kepada mereka untuk melaksanakan proses rekruitmen dengan aturan yang mereka buat sendiri, sehingga menjadi kewenangan mereka untuk melakukan rekruitmen dan menentukan siapa yang menjadi hakim konstitusi.

Terkait proses rekruitmen ini, penulis menemukan bahwa indikasi terjadinya permainan politik kotor dalam menentukan siapa yang lolos menjadi hakim konstitusi terjadi di DPR. Hal ini juga seperti yang disampaikan oleh Dr. Ni'matul Huda yang menceritakan pengalamannya mengikuti seleksi menjadi hakim konstitusi melalui jalur DPR. Kasus yang pernah dialami oleh Dr. Ni'matul Huda adalah dirinya pernah didaftarkan bahkan sampai syarat-syarat administrasinya sudah dilengkapi, padahal Dr. Ni'matul Huda sendiri tidak pernah merasa mendaftar dan mengirimkan berkas pendafataran. Ternyata Dr. Ni'matul Huda didaftarkan oleh salah satu partai politik tanpa meminta izin terlebih dahulu kepada Dr. Ni'matul Huda yang berakhir pada sikap tegas Dr. Ni'matul Huda untuk mengundurkan diri karena merasa tidak sesuai dengan hati nuraninya.

Dari kasus nyata yang penulis dapatkan 
dapat membuka pandangan kita bahwa dalam proses rekruitmen hakim konstitusi sarat dengan intrik politik kotor. Dapat kita bayangkan bila orang yang didaftarkan tersebut adalah orang yang tidak memiliki kompetensi dan kualitas yang tidak mumpuni namun dikarenakan calon dianggap mau kompromi atau bekerja sama demi tujuan tertentu menjadi lolos seleksi. Maka hal itu akan berpengaruh dalam kinerja nya sebagai hakim dalam mengeluarkan putusan. Hal ini juga dalam penelitian yang dilakukan penulis menemukan bahwa di DPR, dalam mendapatkan suara dari DPR ada oknum-oknum yang berusaha melakukan barter suara antara oknum di DPR dengan calon hakim konstitusi.

Barter tersebut biasanya tidak jauhjauh dari masalah kepentingan pribadi atau kelompok, menurut Dr. Ni'matul Huda, oknum-oknum di DPR biasanya menawarkan barter suara dengan sejumlah uang atau kasus. Barter uang artinya, si oknum DPR akan memberikan suara kepada calon hakim konstitusi yang mengikuti seleksi asalkan calon hakim tersebut mau memberikan sejumlah uang kepada oknum tersebut. Sedangkan barter kasus artinya oknum DPR tersebut akan memberikan hak suaranya kepada calon hakim tersebut namun dengan kontrak politik bahwa suatu saat nanti bila hakim tersebut sudah berada di Mahkamah Konstitusi akan memenangkan kasus yang dibawa atau dimiliki oleh oknum DPR tersebut.

Memang hal ini sangat sulit untuk dibuktikan dan dibuka dihadapan masyarakat, sebab ini termasuk permainan politik tingkat tinggi. Namun bukan berarti hal ini hanya dugaan penulis saja, sebab informasi mengenai intrik politik kotor tersebut penulis dapatkan dari orang yang sudah mengikuti langsung proses rekruitmen di DPR. Dan seolah hal ini sudah menjadi rahasia umum, dimana tidak ada yang gratis di Negara ini. Tapi hal ini dapat kita jadikan sebagai gambaran mengenai bagaimana proses rekruitmen akan mempengaruhi kinerja hakim konstitusi yang bisa saja menjadi hakim konstitusi tapi tersandera politik kepentingan atau menang dengan cara yang curang dalam hal ini permainan uang atau barter kasus.

Dalam hal ini penulis melihat bah- wa partisipasi masyarakat dalam mengawal proses rekruitmen hakim konstitusi masih sangat kecil. Bahwa walaupun masyarakat diberikan kesempatan untuk menilai caloncalon hakim konstitusi tetap saja keputusan terletak pada ketiga lembaga tersebut untuk menentukan siapa yang akan menjadi hakim konstitusi. Potensi terjadinya kecurangan dalam menentukan siapa yang akan menjadi hakim konstitusi selalu ada. Namun seperti yang disampaikan oleh Dr. Ni'matul Huda, masyarakat bisa mengawal proses rekruitmen sampai pada batas track record, bagaimana kualitas dan kompetensi calon hakim konstitusi juga bagaimana kualitas penyelenggara seleksi. Namun dalam hal menentukan pilihan siapa yang menjadi hakim konstitusi sudah tidak menjadi public domain lagi, dan disini jugalah potensi terjadinya kecurangan dapat terjadi.

\section{d. Syarat-syarat menjadi hakim konstitusi.}

Hakim Mahkamah Konstitusi adalah seorang negarawan yang memiliki integritas dan perilaku yang tidak tercela. Hal itu memang menjadi sebuah keharusan yang harus dimiliki oleh hakim Mahkamah Konstitusi. Pada Pasal 24C ayat (5) UUD 1945 disebutkan, "Hakim konstitusi harus memiliki integritas dan kepribadian yang tidak tercela, adil, negarawan yang menguasai konstitusi dan ketatanegaraan, serta tidak merangkap sebagai pejabat Negara."

Sampai saat ini syarat-syarat menjadi hakim konstitusi masih menjadi perdebatan diantara para pakar hukum. Syarat yang menjadi perdebatan karena beberapa pakar menganggap syarat tersebut tidak rasional atau tidak dapat dijabarkan dengan jelas. Syarat yang masih ramai diperdebatkan yaitu sifat negarawan dan memiliki integritas. Syarat-syarat hakim konstitusi yaitu diantaranya memiliki integritas dan seorang negarawan tidak mempunyai penjelasan yang pasti pada Undang-Undang Mahkamah Konstitusi. Ketiadaan penjelasan mengenai sifat ini tentu menimbulkan berbagai macam tafsiran dan pandangan yang juga menimbulkan perdebatan mengenai takaran atau pemahaman mengenai integritas dan negarawan tersebut. Negarawan menurut Dr. Ni'matul 
Huda adalah orang yang sudah selesai dengan dirinya sendiri atau tujuannya hanyalah mengabdi kepada Negara saja. Dalam pandangan Dr. Ni'matul Huda, kenegarawanan seseorang tidak dapat diukur berdasarkan umur, namun dapat dilihat berdasarkan track record nya. Hal ini juga sama seperti yang disampaikan oleh Sri Handayani mengenai pandangannya terhadap sifat negarawan, bahwan untuk mengidentifikasi apakah seseorang tersebut negarawan atau tidak dapat dilihat dari track recordnya, karya-karyanya dan perjalanan kehidupan orang tersebut.

Pendapat berbeda disampaikan oleh Prof. Bagir Manan, bahwa menurutnya syarat-syarat hakim konstitusi yang dimuat di dalam UUD terserbut tidak rasional dan tidak dapat diidentifikasi dengan jelas. Sebab tidak ada tolak ukur seseorang dapat dikatakan negarawan, dan memiliki integritas. Bisa saja calon yang selama ini track record nya baik dikarenakan tidak ada kesempatan yang dimilikinya untuk melakukan tindakan tercela atau yang merusak integritasnya. Artinya kita hanya dapat menilai seseorang itu memiliki integritas dan seorang negarawan setelah ia selesai menunaikan tugasnya dengan baik. Kasus yang kita temukan adalah Akil Mochtar mantan ketua Mahkamah Konstitusi. Yang dianggap sebagai seorang negarawan dan memiliki integritas tetap saja dapat terjerat kasus pelanggaran hukum yang merusak nama baik Mahkamah Konstitusi.

Di Negara lain, syarat-syarat untuk menjadi hakim konstitusi lebih terukur. Penulis mengambil contoh syarat hakim konstitusi di berbagai Negara sebagai bahan komparasi.

1. Turki.

Dapat kita lihat secara garis besar bahwa syarat-syarat yang harus dipenuhi bila ingin menjadi hakim konstitusi di Turki adalah paling tidak sudah berumur 45 tahun atau sudah berumur lebih dari 45 tahun, sudah memiliki gelar professor atau yang setara dengan professor (untuk dosen pada perguruan tinggi), aktif melayani sebagai pengacara minimum 20 tahun, sudah menyelesaikan pendidikan tertinggi dan sudah bekerja secara aktif dalam pelayanan publik minimum 20 tahun (untuk senior manager), sudah bekerja selama 20 tahun termasuk masa pencalonan (untuk hakim tingkat satu dan jaksa penuntut umum. (Aksel, 2013:34).

\section{The Central African Republic.}

Untuk Negara The Central African Republic, syarat-syarat yang dibutuhkan untuk menjadi hakim konstitusi yaitu, dipilih dariantara para professor hukum, pengacara, dan hakim yang paling tidak sudah memiliki pengalaman selama 15 tahun. (http://www. concourt.am/Books/harutunyan/monogr3/ dict.htm\#a2)

\section{Kwazulu-Natalithe Federal Republic of South Africa}

Hakim konstitusi diangkat dari antara para pengacara dan konsultan dibidang hukum yang sudah melakukan praktek secara professional lebih dari 20 tahun, professor hukum dan dari antara para hakim dari pengadilan tinggi. (http://www.concourt.am/ Books/harutunyan/monogr3/dict.htm\#a2)

\section{South Korea}

Anggota dari hakim konstitusi di Korea Selatan diangkat dari antara kandidat yang sudah berumur tidak kurang dari 40 tahun, dan sudah memiliki pengalaman berpraktek dibidang hukum tidak kurang dari 15 tahun (sebagai hakim, jaksa, konsultan dibidang hukum, dan pengacara), atau yang sudah memiliki kedudukan yang tinggi di perusahaan public atau sudah menjadi professor hukum. (http://www.concourt.am/Books/harutunyan/ monogr3/dict.htm\#a2)

\section{Peru}

Kandidat hakim Konstitusi di Peru harus memenuhi syarat-syarat sebagai berikut: sudah menjadi anggota pada Mahkamah Agung atau pengadilan tinggi lain selama 10 tahun, atau sudah memiliki pengalaman menjadi professor selama 9 tahun, harus memiliki pandangan hidup yang demokratis, dan menunjukkan kepeduliannya dalam perlindungan hak azasi manusia.

(http://www.concourt.am/Books/harutunyan/ monogr3/dict.htm\#a2)

Mayoritas Negara-negara memberikan 
syarat berdasarkan pengalaman dibidang hukum minimal 15 (lima belas) tahun atau merupakan seorang profesor hukum. Bila kita perhatikan syarat-syarat tersebut, menurut penulis lebih mudah untuk mendefinisikan dan mencari orang-orang yang memenuhi syarat tersebut. Syarat dari 7 negara diatas bila dibandingkan dengan syarat yang diinginkan oleh Pasal 24C ayat (5) UUD 1945 lebih mudah untuk didefenisikan. Menurut penulis sebaiknya syarat-syarat untuk menjadi seorang hakim konstitusi harus lebih real dan dapat didefenisikan dengan jelas sehingga tidak menimbulkan multitafsir. Syarat yang seharusnya diberikan kepada calon hakim Mahkamah Konstitusi harus lah yang dapat diukur dengan jelas, sehingga syarat-syarat yang diinginkan oleh UUD 1945 tidak menjadi syarat yang dapat direalisasikan.

\section{Simpulan}

Kepercayaan masyarakat memegang peranan penting dalam penegakan konstitusi di Negara ini. Kepercayaan masyarakat juga dapat mempengaruhi eksistensi hakim konstitusi yang dijamin oleh undang-undang bila ditemukan melakukan tindakan melawan hukum dan kode etik hakim konstitusi. Kepercayaan yang cukup tinggi masih diperoleh oleh Mahkamah Konstitusi sampai pada saat ini, hal itu dapat dibuktikan dengan melihat bahwa masyarakat masih tetap mengajukan judicial review ke Mahkamah Konstitusi. Bukti lainnya adalah, Mahkamah Konstitusi masih dipercaya dan diharapkan tetap menangangi sengketa hasil Pilkada yang walaupun sudah menyatakan dirinya tidak berwenang untuk menangani sengketa hasil Pilkada melalui Putusan MK No 97/ PUU-XI/2013. Namun demikian, putusan yang dikeluarkan oleh Mahkamah Konstitusi tersebut sudah menimbulkan kekacauan konstitusional, sebab mengeluarkan putusan yang berbeda. Namun tidak terlihat gejolak dimasyarakat yang menolak Putusan MK No 97/PUU-XI/2013 yang membatalkan Putusan MK No 072-073/PUU-II/2004. Menurut penulis, walaupun MK mendapatkan dukungan dari masyarakat, disebabkan oleh putusan yang dikeluarkannya haruslah kita taat konsti- tusi. Artinya kewenangan untuk menangani sengketa hasil pilkada tidak boleh ditangani oleh MK. Menurut penulis, sengketa hasil Pilkada harus diambil alih oleh MA sebagai langkah untuk mengembalikan kepercayaan masyarakat terhadapnya. MA tidak boleh menolak amanat konstitusi, untuk mendukungnya MA dapat belajar cara menangani sengketa hasil Pilkada yang baik kepada MK hal ini dapat dilakukan dengan sistem transfer of system atau transfer of knowledge terkait penanganan sengketa hasil pilkada yang transparan dan akuntabel. Kemudian, untuk semakin meningkatkan kepercayaan masyarakat terhadap kinerja hakim MK dapat dilakukan beberapa hal, yaitu:

a. Menjaga transparansi dan kualitas pelayanan hakim konstitusi dalam hal ini adalah putusan-putusannya

b. Self restricted atau hakim harus dapat membatasi dirinya dalam bergaul dan menerima putusan.

c. Melakukan perbaikan dalam sistem rekruitmen hakim konstitusi agar lebih transparan dan partisipatif serta lebih berkualitas

d. Syarat-syarat menjadi hakim konstitusi harus lebih rasional dan terukur

Dengan demikian diharapkan kualitas pelayanan dan kinerja hakim konstitusi menjadi lebih baik dan semakin meningkatkan kepercayaan masyarakat terhadap lembaga ini. Dengan semakin tingginya kepercayaan yang diperoleh, semangat untuk sadar konstitusi akan lebih baik lagi hingga penegakan konstitusi di Negara ini dapat berjalan lebih baik lagi, hal tersebut untuk semakin mendekatkan kita menjadi Negara yang sejahtera.

\section{Ucapan Terimakasih}

Penulis ucapkan terimakasih kepada pihak-pihak yang telah mendukung penelitian ini baik dalam bentuk materi dan non-materi yakni: Dr. Martitah, M.Hum, Dr. Ni'matul Huda, S.H.,M.Hum, Prof. Dr. H. Bagir Manan,SH.,MCL Sri Handayani, S.IP, M.Si yang menjadi narasumber yang sudah memberikan banyak data dan informasi yang saya butuhkan dalam penulisan ini. 


\section{Daftar Pustaka}

Aksel, Ismail.ebook.2013.Trukish Judicial System.The Ministry of Justice of Turkey, The Department for Strategy Development: Ankara

Martitah.2013.Dari Negative Legislature, MAHKAMAH KONSTITUSI, ke Positive Legislature?. Konstitusi Press (KONpress): Jakarta

Hidayat,Arif. 2011. Tetralogi HAN Buku 2: Dasar-Dasar Hukum Administrasi Negara. Abshor: Semarang Sunggono, Bambang.2013. Metodologi Penelitian Hukum. PT Raja Grafindo Persada: Jakarta

Soemantri, Sri. 2014. Hukum Tata Negara Indonesia Pemikiran dan Pandangan.PT. Remaja Rosdakarya Offset: Bandung

\section{Web}

http://www.concourt.am/Books/harutunyan/monogr3/ dict.htm\#a2 diakses pada 21 Mei 2015 pada pukul 07.54 wib

h t t p : / / n a s i o n a I. ko m pas. com / $\mathrm{read} / 2015 / 02 / 05 / 15050071 / J a l a n$. Tengah.Sengketa.Pilkada diakses pada hari selasa 28 juli 2015 pada pukul 22.57 wib 